\title{
THE ROLE OF NON-PROFIT ORGANIZATIONS IN ENSURING SOCIAL SECURITY ON A LOCAL SCALE
}

The political transformation which started in the early 1990s in Poland aimed to devolve the responsibility for carrying out public tasks away from central government, among other things, and inspired increased social activation. The evolution of legislation, accompanied in some cases by dissatisfaction with decisions made by the state, has resulted in large social movements working for the benefit of sections of society seeking help. The economic transformation of Poland prioritized profit as the main goal of enterprises, which translated into the abandonment of numerous social functions which had previously been offered to employees. This provided opportunities for new organizations to operate in the non-governmental sector, which has slowly emerged as a bridge spanning the structures of the state, society and the private sector. Non-governmental organizations (NGOs) are social entities which aid the state in the areas in which the state is unable to fulfill social expectations and needs. NGOs are not a component of the state system and their activities are not expected to generate profit, making them non-profit organizations. At the same time, they are independent from the public administration from which they inherited the tasks they now perform, which is why they are frequently described as the third sector. Other names interchangeably applied to such entities include $N G O s$, social, civil or voluntary organizations, organizations of social utility or public benefit organizations, charitable and assistance organizations. From the beginning of the political transformation in Poland, and especially after Poland joined the European Union, NGOs have been one of the most active actors in public life and a capable partner to local and regional governments in policy formation. NGOs have taken over a multitude of tasks, also playing an important role in ensuring the sense of social security, the main areas of which are related to the rescue and protection of civilians and assistance for victims of natural disasters, catastrophes, armed conflicts and warfare, both inside and outside of the country. The third sector also supports activities related to public order and security, and prevents social pathologies from developing. It promotes and supports initiatives aimed at the propagation of knowledge and skills related to state defense and the operations of the Armed Forces of the Polish Republic.

It is therefore worthwhile describing the activity of NGOs in the context of social security. The purpose of this paper is not to analyze the concept of security, or to classify different types of security, but rather to discuss the role of NGOs in designing social policy and security at the local level. The core considerations presented here will 
involve the analysis of local partnerships implemented in the Municipality of Stubice, and the cooperation between the municipal authorities and NGOs.

\section{NON-GOVERNMENTAL ORGANIZATIONS AS AN ELEMENT OF SOCIAL POLICY}

In Poland, and in other well-organized developed societies in Europe and the world, three areas of activity, or sectors, in which people and institutions operate can be identified (Bukowska-Piestrzyńska, Gendek-Ufa, 2013: 30):

- public activity in which decisions are made and administrative tasks are fulfilled at the level of state, municipality, or a local institution (public sector);

- profit-driven institutions and organizations (private sector);

- non-profit-driven organizations and institutions operating outside of central and local governments for the benefit of society (NGOs).

Although the terms first sector and second sector are virtually absent from everyday language, the concept of the third sector has caught on and is used by all social, political and business circles. The difference between the third and first sectors is embodied in the very name of the organizations operating in the former: non-governmental organizations. The difference between the third and second sectors is emphasized by the social focus and non-profit character of the former. In contrast to the first and second sectors, operating in the third sector and joining NGOs in civil society is voluntary and reflects the activity of certain groups which share the same ideals or have the same needs and pursue the same ends, instead of seeking profit. The term non-governmental organizations was first used at the United Nations' forum in 1950 during consultations with the non-profit organizations operating independently from governments (Yaziji, Doh, 2011: 27). Western literature uses the terms non-governmental organizations (NGO), private voluntary organizations (PRO) and non-profit organizations (NPO) most frequently.

More organized forms of activity established by certain groups within civil society are generally considered NGOs. However, this category embraces a number of notions which are used interchangeably, although they do not always denote the same thing. The reasons for this terminological diversification may be the following (Halamska, 2008: 15):

- institutions are defined in different socio-political contexts;

- there are many different types of NGOs depending on the culture or the model of the state;

- there are many different theories of the organization of society, for instance the theory of civil society, the theory of social communities and that of social movements;

- the current concepts are gradually maturing and moving from economics, political science and governance sciences to sociology;

That is why NGOs are defined in many different ways. At present, the UN defines NGOs as civil voluntary non-profit groups organized at a local, national or international level, which are task-driven and operated by people sharing similar interests. 
In another place we can read that NGOs are voluntary organizations providing useful goods and services (in the legal sense) which do not generate profits for themselves, thereby serving social purposes (Yaziji, Doh, 2011:27-28). NGOs can be described as contemporary forms of society organizing itself in structures which integrate groups of citizens who are relatively mature in terms of their social awareness; these forms are characterized by a certain level of structuring, they are independent and the initiatives undertaken by them are private initiatives (Frączak, 2011: 204-205).

Polish legislation used the term non-governmental organizations for the first time in the Law of August 27, 1997 on Professional and Social Rehabilitation and Employment of the Disadvantaged. The Law required that the bodies in charge of matters related to the disadvantaged cooperate with NGOs. In the following year, a new administrative division of the country was introduced and the term NGOS was used in the Law of June 5, 1998 on Local Government at the Level of County, and another Law on Local Government at the Level of Region. Article 4 of the former Law states that counties perform public tasks at a supra-municipal level, as stipulated in the regulations, including cooperation with NGOs. Article 12 of the latter Law states that regional governments must develop a strategy of regional development and implement development policy in collaboration with NGOs, among other entities. Other legislative acts featuring the concept of NGOs include the Law on Competences of July 1, 1998, and the Law on Local Government at the Level of Municipality; Article 7 of the latter includes cooperation with NGOs among the tasks of municipalities.

For as long as NGOs have been in existence, there has been no fully regulated system for the state and citizens to support them. Fragmentary regulations were insufficient vis-à-vis the needs and expectations of civil initiatives, which have clearly intensified. This issue was resolved to a large extent by the Law of April 24, 2003 on Activity for Public Benefit and Volunteer Work coming into force. It featured an official definition of this type of activity, which stated that NGOs are not the entities of the public sector nor businesses, research institutions, banks or commercial law companies with legal personality as bodies of central or local governments. They are defined as non-profit organizations, legal persons or as entities without legal personality established on the basis of law, including foundations and associations (Skiba, 2006: 11).

This definition is quite general, which raises considerable controversy both amongst NGOs themselves and in other circles, including legal ones. NGOs can operate as entities with legal personality (associations, foundations, political parties and labor unions) or without legal personality (ordinary associations, university student organizations and countryside women's clubs). The above definition identifies several prerequisites that NGOs should fulfill. It is important that NGOs must not be part of the public sector, ${ }^{1}$ and they also must not be businesses operating in order to generate

${ }^{1}$ The entities of the public sector include the following: public authorities, government administration bodies, public control and law protection bodies, courts and tribunals, as well as local government units and their bodies and associations; (2) public-budget entities, establishments and auxiliary enterprises of public-budget entities; (3) central and local government target funds; (4) state-owned higher education institutions; (5) research and development units; (6) independent public healthcare institutions; (7) central or local government cultural institutions; (8) Social Insurance Institution (ZUS), Agricultural Social Insurance Fund (KRUS) and respective funds managed by them; (9) National Health Fund (NFZ); (10) Polish Academy of Sciences (PAN) and its organizational units; 
profit. However, regulations permit associations and foundations to run business activity provided that this is not their statutory purpose, but only the means of obtaining funding to implement the statutory purpose, and the profit is not distributed among the members of the organization. Another restriction pertains to entities running beneficial activity (whether as part or whole of their operations) whose organizational and legal form is atypical of NGOs, such as capital commercial law companies, cooperatives and local civic organizations which are not entered into the National Court Register. The Law on Activity for Public Benefit and Volunteer Work introduces the definition of activity for public benefit; pursuant to Art. 3.1, it should be understood as socially beneficial activity run by non-governmental organizations in the field of public tasks stipulated in the same Law.

The entities authorized to apply for the status of public benefit organization include legal persons, organizational entities operating on the basis of the regulations on the relationship of the Church to the State and to other churches and religious associations, and associations of local government units (Ceglarski, 2005: 25-36).

The following NGOs have been excluded by law as potential public benefit organizations (Kurleto, 2007: 66-67): political parties, labor unions, employers' organizations, professional organizations, companies operating on the basis of regulations on physical culture, and some foundations. Regardless of the legal form of operation, the entities whose activity is even partly not related to public benefit cannot get the status of public benefit organizations. Taking into account all the aspects of the business activities that NGOs might conduct, the following needs to be borne in mind (after: Bukowska-Piestrzyńska, Gendek-Ufa, 2013: 31): (1) business activity must not be the purpose of the organization; (2) it must conform to the organization's statute, but must not be the same as the statutory activity; (3) business activity must constitute an appropriate proportion of the organization's statutory activity; and (4) the income generated from business activity must not be distributed among the organization's members.

Article 4.1 of the Law itemizes the forms of collaboration between public administration and organizations. The 33 tasks identified there include social assistance, family assistance and assistance provided to persons in difficult life situations, such as the disadvantaged, the excluded or persons at risk of social exclusion, immigrants, senior citizens, children and young people. NGOs are also active in the field of healthcare, markets, the labor market and development of entrepreneurship. They may also undertake all kinds of activities related to teaching, training, child-rearing and education, including university education. Important tasks for NGOs include those related to culture, art, protection of cultural and national heritage, protection of environmental heritage, and the promotion and organization of voluntary and charitable activities.

NGOs may also perform an extensive range of tasks related to social security, in particular in relation to rescue operations and protection of the population and assistance for victims of natural disasters, armed conflicts and wars, both within and outside of national borders. The third sector also supports activities which influ-

(11) central or local government legal entities established on the basis of separate acts in order to perform public tasks, excluding enterprises, banks and commercial law companies. 
ence public security and order, and prevents social pathologies from developing. The third sector supports and promotes initiatives aiming to disseminate knowledge and skills related to state defense and the operations of the Armed Forces of the Republic of Poland.

The extensive range of the tasks which NGOs may perform makes them partners in practically any field, and their fulfillment of the needs of local communities inspires a sense of security amongst the population.

NGOs can be classified in terms of two different criteria (Yaziji, Doh, 2011: 28-29):

- who they serve;

- what they do.

The first criterion determines the beneficiaries of the organization's activity. They include those social groups which have come together to form organizations in order to deliver some benefits to their members, usually by means of combining their shared interests. Their donors or workers belong to the group of target beneficiaries. These are the so-called self-help organizations, such as labor unions, commercial associations, church groups, neighborly assistance groups, amateur sports club or Alcoholics Anonymous. Another type of organization encompasses those whose target beneficiaries do not contribute capital or work in order to generate benefits only for themselves or for the groups indicated by them, and the benefits are distributed among larger sections of society instead. These are caring organizations, such as global enterprises - Greenpeace, Doctors Without Borders (MSF), World Wildlife Fund (WWF), CARE or Amnesty International (ibid:: 30-31).

The other group of organizations identified in terms of what they do includes:

- advocacy NGOs;

- service NGOs;

- hybrid NGOs.

Advocacy organizations aim to establish a social, economic or political system for the purpose of promoting certain interests or ideologies. They are lobbyists, they take a stand as representatives and advisors facilitating decision-making, they organize conferences, conduct research, participate in different kinds of elections, stage protests and influence investors. In other words, advocacy NGOs express opinions enabling different institutions to promote social activity while curbing the side effects of business operations. They can be divided into watchdog organizations and social movements. The mission of the former is not to destroy the current system but to ensure that businesses, legislative, political and social organizations observe respective regulations. The situation is different in the case of social movements, which do not endeavor to support the current system but to change or undermine it. Service NGOs are oriented at providing goods and rendering services for specified groups whose needs are not otherwise fulfilled. This is exemplified by organizations operating in indebted or corrupt states, which either do not want or are unable to fulfill social needs (e.g. WWF or the Red Cross). Hybrid NGOs combine the two above-mentioned types of activities - advocacy and services - or move from one to the other. This mode of operation is gaining popularity. Hybrid NGOs operate in this way by trying to adapt to the constantly changing situation in order to meet the needs of the groups they are supposed to assist (ibid.: 32-36). 


\section{TASKS OF MUNICIPAL LOCAL GOVERNMENT ENSURING SOCIAL SECURITY}

To a large extent, ensuring public security is the responsibility of territorial governments and central administration. Public institutions make sure that this activity continues seamlessly by the monitoring and prevention of threats at every level.

One of the roles of territorial self-government is to fulfill the basic needs of their residents and seek to make them feel safe in their community. Thus local authorities are assigned responsibility for the identification of threats, and for the prevention and elimination of threats that have already emerged, to protect society and the environment. In keeping with its role and the subsidiarity principle, a local government is responsible for carrying out activities in its territory whereas central government supervises and coordinates them. A competent municipal government will have no problems with identifying the needs of its community and fully meeting them. It will respond to catastrophes, social problems or unfortunate incidents quickly and efficiently. Fulfilling its tasks it will also be able to have influence on the level of security of people in all areas.

Territorial self-government is formed by the local community, which can co-decide on the implementation of policies which are a direct outcome of the community's needs. Due to a new administrative division, municipalities are given a large, open catalogue of responsibilities. Article 6.1 of the Law on Municipal Government emphasizes that "the remit of municipal activities covers all public matters of local significance which are not restricted by law as belonging to other entities" (Ustawa, 1990: Art. 6.1). Article 7.1 rules that it is a municipal task to meet the collective needs of the community. Municipality should first and foremost care for spatial order, real estate management, protection of the environment and nature and water management. Another responsibility of municipal government involves the maintenance of roads, streets, squares and bridges, as well as the organization of traffic. Other essential tasks involve ensuring water supply to residents, maintenance of the sewage and water supply networks, sewage removal and treatment, maintenance of cleanliness and order, maintenance of sanitary facilities, garbage dumps and disposal of municipal waste, and ensuring electricity, heating and gas supplies. The municipality is responsible for the maintenance of public order and security and fire and flood protection. It is also obliged to supply and maintain the municipal flood warehouse.

The municipality is also tasked with providing public transportation, construction, telecommunications and healthcare. It fulfills residents' needs regarding social assistance and providing access to care centers and facilities. It also has to enact familyfriendly policies, provide social, medical and legal assistance for pregnant women and support families and the foster care system.

As part of its remit, the municipality assists education, culture, libraries, institutions of culture and protection of historical monuments, and enforces such protection. It fosters the development of physical culture and tourism, recreation areas and sports facilities.

Individual tasks of every municipality also include the maintenance of public facilities, as well as all administrative facilities, market halls, markets, municipal greenery and trees and municipal cemeteries. 
Every municipality is also expected to promote its own activities, provide favorable conditions for the development of auxiliary entities, implement civil activation programs and cooperate with NGOs operating in the municipality as partners. The municipality should also be open to contacts with other local governments and communities at the regional, national and international level.

The above list includes the major tasks which should fulfill the collective needs of local communities. However, in the face of technological progress and increasingly frequent threats to security, this catalogue of needs is expanding. Therefore, the administration has to be prepared for new challenges in the field of social security and for new types of partnerships capable of facing the challenges of modern world. Public institutions are obliged to perform their tasks and resolve social issues. This is a legislative requirement. In order to fully perform their tasks, public institutions have to earmark adequate resources in their budgets, set the principles of their allocation and establish the principles of operation of social infrastructure.

\section{LOCAL PARTNERSHIPS AS AN OPPORTUNITY TO DEVELOP THE COMMUNITY; THE EXAMPLE OF THE SŁUBICE MUNICIPALITY}

Partnership and cooperation with the third sector constitutes an essential element of the functioning of local communities. No-one can operate alone and even the strongest leaders need the support and collaboration of other people, institutions, social groups and other entities. What is crucial in this case is that cooperation produces synergy, thereby allowing duplication of the same activities by different organizations to be avoided. For partnership to emerge in a given territory, collaboration between different institutions is important. Much depends on the local government and its openness to relations with the social and private sectors. Launching genuine cooperation contributes to improved quality of life for residents, and, therefore, their sense of security. Local social policy has a significant instrument at its disposal, namely a new European Territorial Cooperation (ETC) Interreg VA. Residents may also find the Community-led Local Development (CLLD) instrument interesting. Implemented by a Local Action Group, it will offer a chance for the local community to develop in many strategic areas. Partnerships and the process of building them are tested as to the ability of establishing relations aiming to assist the excluded or those in danger of exclusion. The Municipality of Słubice is facing a considerable advantage provided by a social economy which, in the current financial perspective, is supposed to make a considerable contribution to solving major social problems, as it offers an extensive range of instruments ranging from know-how to financial support.

In line with the regulations in the Multiannual Financial Framework 2014-2020, Poland will receive EUR 82,177,555,129.00. A total of eight operational programs will be implemented on the national level. On top of that, there will be 16 Regional Operational Programs (ROP).

There are sixteen operational programs in the pipeline at the regional level. The Regional Operational Program for the Lubuskie Region will be launched based on the 
Detailed Description of Priority Axes. There are ten axes. The total amount earmarked for the Lubuskie Region is EUR 906,929,693.00

Axis VI will be of particular importance for the region as it will support the local labor market. The activities in this field will be addressed at people facing problems in the labor market: the unemployed, both registered and unregistered at the labor office, and individuals who have been or are going to be made redundant. Similarly to the previous perspective, this one also provides for those who intend to establish a business to receive non-refundable grants or repayable financial instruments for the start-up. The axis will support the promotion of gender equality on the labor market and assist enterprises adjusting to new economic conditions.

Priority axis VII (Social integration) concerns social integration and inclusion of those who are socially excluded or in danger of social exclusion. Within the framework of the axis, Social Economy Support Centers will operate to comprehensively handle the permanent professional and social integration of people in danger of exclusion. They will also facilitate the setting up of social enterprises, and enhance the quality of operation of existing entities.

Educational projects for different recipient groups will be supported under Axis VIII. Subsidies will be provided for preschool children, pupils in elementary schools, and students in junior and senior high schools. This axis will also support educational projects for adults wishing to expand their competences and acquire additional skills required on the labor market.

Axis IX is related to social infrastructure, in terms of healthcare, social services, educational infrastructure and support for marginalized areas. Axis X is related to technical support facilitating the management of the ROP for the Lubuskie Region and its implementation.

Under the new financial perspective, a new instrument of Community-led Local Development (CLLD) was set up. This mechanism will enable local communities to initiate and implement development activities, establish Local Action Groups (LAG) and carry out participatory design and implementation of Local Development Strategies (LDS). "This instrument deserves particular attention due its participatory character, embodied by the involvement of local communities and partners - local government, business and the non-governmental sector - in the creation and implementation of LDSs. That is why the Partnership Agreement provides for solutions which will assist the development of the CLLD under cohesion policy" (Umowa Partnerstwa, 2014: 208). The Municipality of Stubice is a member of the Local Action Group led by the Stowarzyszenie Zielona Dolina Odry $i$ Warty [Association of the Green Valley of the Oder and Warta Rivers]. The Association covers the North-West of the Lubuskie Region, which includes seven municipalities: Cybinka, Górzyca, Kostrzyn nad Odrą, Rzepin, Słońsk, Słubice and Witnica. The LAG area is inhabited by 76,869 people (as of December 31, 2013).

Local Development Strategies have four major goals which should assist the nongovernmental sector and residents in implementing the program. These goals are as follows:

1) developing a resident-friendly region which encourages people to settle,

2) social capital development,

3) economic development of the LAG region, 
4) making the region attractive for tourists.

The strategy will be implemented by applying the novel method of contests for grants which, thanks to social consultations, will be developed in participation with the local population. Three such contests will be organized and carried out within Objective 2: Social capital development:

1) Our products from the Oder and Warta region - this contest is addressed at NGOs operating in the seven municipalities covered by the LAG. The contest will make it possible to obtain funds for initiatives developing local identity and promote a highly extensive range of products (craft products, culinary products and products related to tourism, education, culture and art). The contest will give NGOs the resources to develop a product which will later serve the local community. The largest grant may amount to PLN 15,000 (ca. EUR 3,700);

2) Our places - a contest for NGOs. Support from this source may be used to develop public space, refurbish and furnish facilities used by local residents, develop new places promoting social activity, and reclaim degraded areas. A grant of up to PLN 20,000 (ca. EUR 5,000) will be available to this end;

3) GREEN Valley of the Oder and Warta Rivers - contests organized in this category will pursue goals related to environmental protection, innovation, countering the effects of climate change and maintaining a high quality of natural environment in the LAG. The participation of residents will make them jointly responsible for the protection of nature which will translate into increased social awareness in this respect. A grant of up to PLN 40,000 (ca. EUR 10,000) will be available.

Apart from these subsidies, which will be available for the purpose of the development of the local population, NGOs cooperating with the local government will also be able to take part in the implementation of Objective 1 of LDS, which envisages allocation of aid to the construction, revamping or equipping of general non-commercial tourist, recreational, cultural or road infrastructure.

The remaining strategic objectives, Objective 3 and 4, will be available to all entities. Objective 3 is directly linked to the development of entrepreneurship. Resources will be allocated to the setting-up and development of businesses by means of grants. Objective 4 in turn primarily involves promotion of the region, with NGOs' participation, mainly in the form of Local Action Groups.

The major outcome of the strategy will be increased participation of residents of the municipalities covered by the LAG in the whole process. A measurable indicator will be provided by the value of all projects implemented by the civil sector. In the period 2007-2013 this indicator was only $4.2 \%$. The goal of the financial perspective 2014-2020 is to raise this indicator to $30 \%$.

\section{COOPERATION OF THE MUNICIPAL LOCAL GOVERNMENT WITH NGOS IN SLUBICE}

NGOs are among the major and most active participants in public life which collaborate with local authorities. The main reason for this is that the idea of civil dialogue is afforded considerable importance, which is most frequently defined in terms of direct relations and 
influence exerted by citizens on public policies via social organizations. The idea of civil dialogue places NGOs in the position of social negotiators on behalf of the public. Numerous procedures and adequate instruments have been created to this end, such as social consultations and public hearings. The range of possible areas of operation available to social organizations is very large. On the one hand, they may act as contractors; on the other, they can co-create and design different dimensions and levels of public life.

The Słubice Municipality is represented by over seventy NGOs, only half of which are active. The organizations operating there are initiatives founded by residents in order to meet different needs and solve current social issues. They cover a broad spectrum of activities, ranging from education for different age groups, through culture, art and sports, to assisting those most in need.

The high quality of organizations and their development requires effective cooperation between the third sector and local government, as cooperation is imperative when municipal problems need to be resolved and different needs have to be fulfilled. Yet it is not always easy. Problems may be generated by undertaking activities which are not appropriate for the requirements, or by organizations applying routine solutions rather than talking to people and asking about their needs. The outcome is that projects and public tasks are replicated and people working in the sector are not interested in training to expand their skills.

Successful cooperation between the municipal local government in Słubice and NGOs can be exemplified by the Consult-and-decide project, implemented by the Foundation for Collegium Polonicum with the Municipality as a partner. The project resulted in the emergence of an intersectoral group, Paperclip Stubice Initiative, which undertook to develop three documents intended to facilitate cooperation between NGOs and the local government. The main objective of this endeavor was to increase the awareness of NGO representatives and the municipal government in Stubice regarding social participation and its role in creating civil society. Another task was to entrench the process of social consultations and popularize them among the public. The Consult-and-decide project initiated a series of changes in the Słubice Municipality. Local initiative has become firmly established in Stubice and accepted by the City Council as a general rule. Although the funds were spent slowly in the first year, in 2016 they were exhausted within the first quarter of the year, and residents of the municipality benefited from many valuable initiatives.

The Paperclip initiative also deserves to be mentioned. It brought together representatives of the City Council, employees of the City Hall and activists from local NGOs. The group started its work with training sessions attended by representatives of both sectors. The idea behind the training was to facilitate closer cooperation between residents and the local government, involve the local community in decision-making on important matters, and develop the attitudes of all stakeholders' shared responsibility for the development of the municipality. Due to both sectors being involved in the work of the Paperclip, dialogue began and a package of civil-inspired resolutions was jointly developed. The Paperclip participants managed to design the principles and mechanism of social consultations, the program of cooperation with NGOs, as well as the procedure and detailed assessment criteria regarding applications for public tasks implemented as local initiatives. 
The strong commitment of municipal councilors and officers deserves to be stressed, as this made the whole process successful. The legislative and executive authorities of the Słubice Municipality did not interfere with the remit of the Paperclip project. This is evidence that both parties trusted each other and that the common good was important for all. The Paperclip is a group of leaders who demonstrate a new quality of cooperation, the sense of agency and increased participation of NGOs and, consequently, residents in municipal decision-making. The Paperclip and the solutions developed in the course of its work will serve the residents well. This is common good which will increase the sense of responsibility for local development.

$* * *$

Poland is witnessing a revival of NGOs. Despite numerous difficulties, 86,000 associations are in operation (the researchers excluded Volunteer Fire Brigades), as well as 17,000 foundations. Approximately $30 \%$ of organizations are inactive. As well as organizations with long traditions, many new ones have emerged to deal with the problems and needs of modern society. They run multifarious activities in practically all walks of life. The intensive development of the third sector is, among other things, the outcome of the enormous human energy released both in business and in social activities when the free market economy entered Poland. Third sector organizations assist other parties by mediating between society, including individual groups in society, the state and the market, and by rendering social services and implementing socially beneficial objectives. They are increasingly proficient in helping society adapt to a new reality, as well as to understand it, and involve people in cooperation and the creation and carrying out of projects which enable them to identify with the European Union. They play an important role, both nationwide and regionally. In order to increase the efficiency of NGOs' further work on several levels, the following is required:

- NGOs need to be strengthened and their image reinforced in communities, as NGOs require public recognition and can respond to public needs;

- effective inter-sectoral cooperation has to be established between local governments, organizations and businesses to utilize the resources all these entities have;

- human capital needs to be developed in municipalities in order to build the environment of social economy and assistance to those in greatest need;

- subsidies for municipal development need to be sought as all obtained resources support and enhance social capital.

NGOs are an important element of democracy and civil society. It is imperative to be able to establish good relations between the third sector and territorial self-government entities in order to delegate tasks, thereby efficiently conducting a social policy which protects the security of citizens.

\section{Bibliografia}

Bukowska-Piestrzyńska A., Gendek-Ufa K. (2013), Działalność organizacji pozarządowych, „Ekonomia i Organizacja Przedsiębiorstw”, nr 1, Wydawnictwo Instytut Organizacji i Zarządzania w Przemyśle „ORGMASZ” Warszawa. 
Ceglarski A. (2005), Organizacje pożytku publicznego, Wydawnictwo Prawnicze LexisNexis, Warszawa.

Ciekanowski Z. (2010), Rodzaje i źródła zagrożeń bezpieczeństwa, Warszawa, http://czytelnia. cnbop.pl/czytelnia/6/11, 18.04.2017.

Frączak P. (2011), Partnerstwo czy uzależnienie? Rzecz o autonomii organizacji pozarządowych, w: Filozofowie o autonomii, red. Sz. Wróbel i in., Rocznik Naukowy Zoon Politikon, Centrum Badań Społeczności i Polityk Lokalnych, Warszawa.

Gierszewski J. (2013), Bezpieczeństwo społeczne, Difin, Warszawa.

Gierszewski J. (2013), Organizacja systemu bezpieczeństwa społecznego, Difin, Warszawa.

Grzywna P. (2014), Demograficzne aspekty bezpieczeństwa spotecznego Polski na poczatku XXI wieku, w: Dylematy polityki bezpieczeństwa Polski na poczatku drugiej dekady XXI wieku, Katowice.

Halamska M. (2008), Wiejskie organizacje pozarzadowe. Wprowadzenie, w: Wiejskie organizacje pozarządowe, red. M. Halamska, Instytut Rozwoju Wsi i Rolnictwa PAN, Warszawa.

Kurleto M. H. (2008), Organizacje pozarządowe w działalności pożytku publicznego, Wydawnictwo Prawnicze LexisNexis, Warszawa.

Kwiatkowski S. (2011), Zarzadzanie bezpieczeństwem w sytuacjach kryzysowych. Szkice socjologiczne o mąrości przed szkoda, Pułtusk.

Musiał-Karg M. (2014), Diagnoza aktywności obywatelskiej, w: Diagnoza lokalnych problemów $i$ wyzwań powiatu stubickiego, red. M. Musiał-Karg, Słubice.

Pawłowski J. (2002), Słownik terminów z zakresu bezpieczeństwa narodowego, Warszawa.

Pietraś M. (2000), Bezpieczeństwo ekologiczne w Europie, Wyd. UMCS, Lublin.

Rosicki R. (2010), O pojęciu i istocie bezpieczeństwa, „Przegląd Politologiczny”, nr 3.

Skiba R. (2006), Prawne warunki działania organizacji pozarzadowych-modut 1, Akademia Filantropii w Polsce, Warszawa.

Skrabacz A., Sulowski S. (2012), Bezpieczeństwo społeczne. Pojęcia uwarunkowania wyzwania, Elipsa, Warszawa.

Słownik terminów z zakresu bezpieczeństwa narodowego (2008), AON.

Yaziji M., Doh J. (2011), Organizacje pozarządowe a korporacje, Wydawnictwo Naukowe PWN, Warszawa.

\begin{abstract}
The democratic transformation in Poland, the beginning of which dates back to the 1980s, brought political and economic freedom that additionally inspired the activity of civil movements taking the form of non-governmental organizations. Since the early 1990s, Polish society has become clearly divided, which was illustrated by the emergence of three distinct areas of public activity. The Law of March 8, 1990 on Territorial Self-Government began the rapid development of local governments, which were given the task of handling local public matters. The Law on Business Operations, which was in force at the time, ensured freedom of operations and the principle of quality of all participants of business life. Other laws, the Law on Foundations of April 6, 1984 and the Law on Associations of April 7, 1989 restored the possibility of civil self-organization, working for one's own circle and fulfilling social needs. Throughout the whole period of political transformation, and in particular in the decade after Poland's accession to the European Union, NGOs have become one of the most active actors of public life, and
\end{abstract}


a capable partner to local and regional authorities in designing policies. One significant element of politics involves ensuring the security of citizens. Social security is of particular importance. NGOs initiate a number of projects aiming to fulfill the basic needs of residents, thereby ensuring their personal development and confidence. Cooperation with territorial self-government is of exceptional importance here.

Keywords: non-governmental organizations, third sector, social security, tasks, partnership

\section{MIEJSCE ORGANIZACJI NON-PROFIT W KSZTALTOWANIU BEZPIECZEŃSTWA SPOLECZNEGO W WYMIARZE LOKALNYM}

\section{STRESZCZENIE}

Przemiany demokratyczne w Polsce, których początek sięga lat 80. dwudziestego wieku spowodowały, że poza wolnością polityczną i gospodarczą uaktywnił się ruch obywatelski w formie organizacji pozarządowych. Od początku lat dziewięćdziesiątych w polskim społeczeństwie doszło do czytelnego podziału, czego wyrazem było wyodrębnienie się trzech sfer działań publicznych. Wejście w życie ustawy z 8 marca 1990 r. o samorządzie terytorialnym spowodowało dynamiczny rozwój wspólnot samorządowych, którym oddano do realizacji sprawy publiczne o charakterze lokalnym. Funkcjonująca wówczas ustawa o działalności gospodarczej umożliwiała swobodę działania i zasadę równości w traktowaniu wszystkich uczestników życia gospodarczego. Natomiast ustawy: o fundacjach z 6 kwietnia 1984 r. i stowarzyszeniach z 7 kwietnia 1989 r. ponownie stworzyły możliwości samoorganizowania się obywateli, działania na rzecz swoich środowisk oraz zaspokajania potrzeb społecznych. Przez cały okres transformacji ustrojowej, a zwłaszcza w ostatnim dziesięcioleciu, po akcesji Polski do Unii Europejskiej, organizacje pozarządowe stały się jednym z najbardziej aktywnych aktorów życia publicznego, sprawnym partnerem władzy lokalnej i regionalnej w kreowaniu polityki. Ważnym elementem polityki jest zapewnienie bezpieczeństwa obywatelom. Szczególnie istotnym jest bezpieczeństwo społeczne. Organizacje pozarządowe wychodzą z szeregiem inicjatyw mających na celu zaspakajanie podstawowych potrzeb mieszkańcom, tym samym dając gwarancję na rozwój osobisty i poczucie pewności. Szczególną rolę odgrywa tu współpraca z samorządem terytorialnym.

Słowa kluczowe: organizacje pozarządowe, III sektor, bezpieczeństwo, społeczne, zadania, partnerstwo 
